\title{
アクアガス（微細水滴含有過熱水蒸気）による 農産物の加熱殺菌効果
}

\author{
増田弥恵・殿塚婦美子・香川芳子 \\ (女子栄養大学) \\ (平成25年12月 7 日受付, 平成26年 8 月 4 日受理)
}

\section{Heating sterilization of vegetables by Aqua-Gas (micro-water droplets containing superheated steam)}

\author{
Yae Masuda, Fumiko Tonozuka, Yoshiko Kagawa \\ Kagawa Nutrition University, 3-24-3, Komagome, Toshima-ku, Tokyo, 170-8481 \\ 干170-8481 東京都豊島区駒込3-24-3
}

\begin{abstract}
With the growing interest among consumers for food safety, many food service and catering facilities use the microbial sterilization of food by the scientific sterilization method; the chlorite and electrolyzed water acidic aqueous solution. However, this method is accompanied by residual chlorine and the drastic decrease in runoff of soluble nutrients and flavor due to the inevitable rinse with plenty of water.

Compared to this conventional way, Aqua-Gas (micro-water droplets containing superheated steam) can sterilize many vegetables without requiring a scientific sterilization method. Aqua-Gas has a higher heat transfer by control of the heating drying speed and possible adjustment of the moisture content of the ingredients heating by containing micro-droplets of superheated steam in the atmosphere. A remarkable bactericidal effect in a short time by the aquagas-treated heat occurs when compared to other heating methods with a high heat transfer efficiency, and the effects on the microbial control of the agricultural surface are already occurring, especially for vegetables and raw heating.

Results of the bactericidal effect on the extension of the viable cell count due to the aquagas-treated heating sterilization revealed that purpose of the various ingredients of the souring heating time on the measurement and experiment, and the heating time during the aquagas-treatment in many agricultural products, 10 seconds became safe and hygienic while retaining the texture life in 30 seconds. Also concerning the viable cell count due to the aquagas-treated heating ingredients, the viable cell count increased even after 96 hours of chilled storage, thus an increase in the shelf-life could improve the sterilization effect. Aquagas-treated heating having a high bactericidal effect suggests that it can lead to a simplification of work processes such as pre-heating and heat the ingredients faster.
\end{abstract}

\section{1. 緒言}

食品の安全性に対する消費者の関心が高まっている中, 2011（平成23）年 6 月に農林水産省消費・安全局から農 産物を衛生的に保つための衛生管理指針が公表された ${ }^{1)}$ 。
国内外に执いて農産物の生産段階での微生物污染が原因 とされる集団食中毒も起きており，生産段階に扔ける微 生物の付着・増殖を予防する重要性が重視されている。 一方, 食品の微生物污染状況は流通・販売過程における 保存状態等にも大きく影響されるため, 多くの外食産 
業・給食施設等では微生物殺菌方法として次覀塩素酸塩 や電解水強酸性の水溶液による科学的殺菌法を用いてい る。しかし，この方法で殺菌効果を高めるには溶液浸漬 時間がきゅうりの場合は30分以上を必要とすることや2) 野菜に塩素が残留することが明らかになっている ${ }^{3)}$ 。ま た多量の水による洗い流しによって水溶性栄養成分の流 出を伴うことも否めず，薬剤等を使用せずに微生物を制 御できることが望ましい。

このような背景において農産物等の表面殺菌処理に過 熱水蒸気による加熱が検討されている ${ }^{4)}$ が, この加熱方 法では食材表面が乾燥状態となる。そこで, 加熱による 乾燥速度を制御し食材の含水率を調整でき, かつ従来の 過熱水蒸気より高い熱伝達性を持つ加熱方法が開発され た。高温の微細水滴を含有した常圧の過熱水蒸気雲囲気 (アクアガス $)^{5)}$ 加熱である。この加熱方法は, 軟水処理 した水を 2 つ加熱プレート内でヒーターより加熱し, 加熱チャンバー内のノズルから噴霧させる。加圧された 加熱プレート内で $115 \sim 120^{\circ} \mathrm{C}$ に加熱された水はチャン バー内で大気圧に戻り蒸発し水蒸気化し，この微細水滴 の混在した状態をアクアガスと定義している ${ }^{6,7)}$ 。アク アガス加熱は, 他加熱法と比較して熱伝達効率が高く, 農産物表面の微生物制御に対する効果があることがすで に明らかになっている。なかでも農産物の生の食感を損 なわない短時間での加熱における殺菌効果が著しい ${ }^{8-11) 。 ~}$ 本報では，外食産業・給食施設等で使用頻度の高い農 産物について, より調理の現場に即した観点から, 生の 食感を保持しつつ衛生的に安全なレベルまで微生物を制 御できる加熱時間における微生物検査と, 生食および加 熱食材の加熱後の一般生菌数の経時変化およびアクアガ 久加熱時間延長の殺菌効果を検討したので報告する。

\section{2. 実験方法}

\section{（1）試料および試料の調製}

本実験では，1）生食する食材のアクアガス加熱にお ける短時間加熱殺菌効果，2）生食および加熱食材の加 熱後の一般生菌数の経時変化，３）アクアガス加熱時間 の延長と殺菌効果について行った。試料はアクアガス加 熱の特徵的な調理加工特性である短時間加熱殺菌を生か したレシピ12) から選定した。各々豊島区内小売店より購 入し，提供される際に頻度の高い切り方に調製した。な お以下，洗浄は水道水を用い給食施設の洗浄方法に準じ た。未加熱のものについては，洗浄は行っていない。

\section{1 ）短時間加熱殺菌}

\begin{tabular}{|ll|}
\hline かぶ & 葉を切り落とし洗浄後, 皮を剥き $3 \mathrm{~mm}$ の \\
& 半月切り \\
ミニトマト & ヘタを取り洗浄 \\
カット野菜 & 購入時のまま \\
巨峰 & 房を取り皮付きのまま洗浄 \\
メロン & 洗浄後皮付きのままくし型にカット \\
レモン & 洗浄後皮付きのままくし型にカット
\end{tabular}

\begin{tabular}{|ll|} 
キャベッ & 外葉除去後葉をばらばらにして洗浄し $3 \sim$ \\
パセリ & $4 \mathrm{~cm}$ のざく切り・ $5 \mathrm{~mm}$ 幅のせん切り \\
大根 & 洗浄 \\
& 洗浄後皮を剥き洗浄後 $5 \sim 6 \mathrm{~cm}$ のマッチ \\
カットパイン & 棒大にカット \\
購入時のまま \\
赤たまねぎ & 皮を剥き洗浄後 $5 \mathrm{~mm}$ の薄切り \\
ピーマン & 洗浄後種子を除去し $5 \mathrm{~mm}$ 幅のせん切り \\
にんじん & 洗浄後皮を剥き $2 \mathrm{~mm}$ のせん切り \\
きゅうり & 専用スポンジでこすりながら流水で洗浄, \\
& 洗浄後 $3 \mathrm{~mm}$ の口切り・せん切り \\
\hline
\end{tabular}

\section{2 ) 一般生菌数の経時変化}

\begin{tabular}{|ll|}
\hline もやし & 洗浄 \\
きゅうり & 専用スポンジでこすりながら流水で洗浄, \\
& 洗浄後 $3 \mathrm{~mm}$ の小口切り・せん切り \\
かいわれ大根 & 根を取り洗浄 \\
長ねぎ & 根を切り落として洗浄 \\
カリフラワー & 小房に切り分けて洗浄 \\
ブロッコリー & 小房に切り分けて洗浄 \\
たまねぎ & 皮を剥き洗浄した後 $5 \mathrm{~mm}$ の薄切り \\
レモン & 洗浄 \\
はくさい & 外葉除去後葉をばらばらにして洗浄し $3 \sim$ \\
& $4 \mathrm{~cm}$ のざく切り \\
にら & 洗浄後 $3 \sim 4 \mathrm{~cm}$ の長さにカット
\end{tabular}

\section{3 ） アクアガス加熱時間の延長と殺菌効果}

\begin{tabular}{|ll|}
\hline きゅうり & 洗浄後 $3 \mathrm{~mm}$ の小口切り・せん切り \\
根三つ葉 & 根を切り落とし $3 \mathrm{~cm}$ の長さにカットし洗 \\
& 浄 \\
にら & 洗浄後 $3 \sim 4 \mathrm{~cm}$ の長さにカット \\
かいわれ大根 & 根を取り洗浄 \\
万能ねぎ & 根を切り落とし洗浄後 $3 \mathrm{~mm}$ の小口切り \\
カット野菜 & 購入時のまま \\
たまねぎ & 皮を剥き洗浄後 $5 \mathrm{~mm}$ の薄切り \\
もやし & 洗浄 \\
セロリ & 葉と根に近い部分を切り落とし専用スポン \\
& 艺で洗浄 \\
長ねぎ & 洗浄後 $3 \mathrm{~mm}$ の小口切り \\
マッシュルーム & 洗浄 \\
ブロッコリー & 小房に切り分けて洗浄 \\
青梗菜 & 根元を切り落とし洗浄後葉はざく切り, 荃 \\
& は削ぎ切り \\
おくら & なり口を切り落とし洗浄 \\
\hline
\end{tabular}

\section{（2）使用機器・加熱条件}

アクアガス加熱装置「アクアクッカー」[株式会社夕 イヨー製作所（厨房型 AQ-25G-SD5-OH）を使用した （外形寸法 W1067 mm × D1120 mm × H890 mm, 可能処 理量 1 / 1 ホテルパン 5 枚, 電源 A C 200V 3 相, 消費電 力 $8 \mathrm{kw})$ ○アアガスの発生メカニズムについては図 1 に示した。詳細は既報も参照されたい ${ }^{13,14)}$ 。

アクアガス状態を決定する加熱条件となる庫内蒸気量 (spm) とファン回転速度 $(\mathrm{Hz})$ については, 80〜 $360 \mathrm{spm}, 25 \sim 50 \mathrm{~Hz}$ の各段階で庫内温度上昇実験を行っ た結果を検討し，最適と思われる $200 \mathrm{spm} ・ 25 \mathrm{~Hz}$ に設 


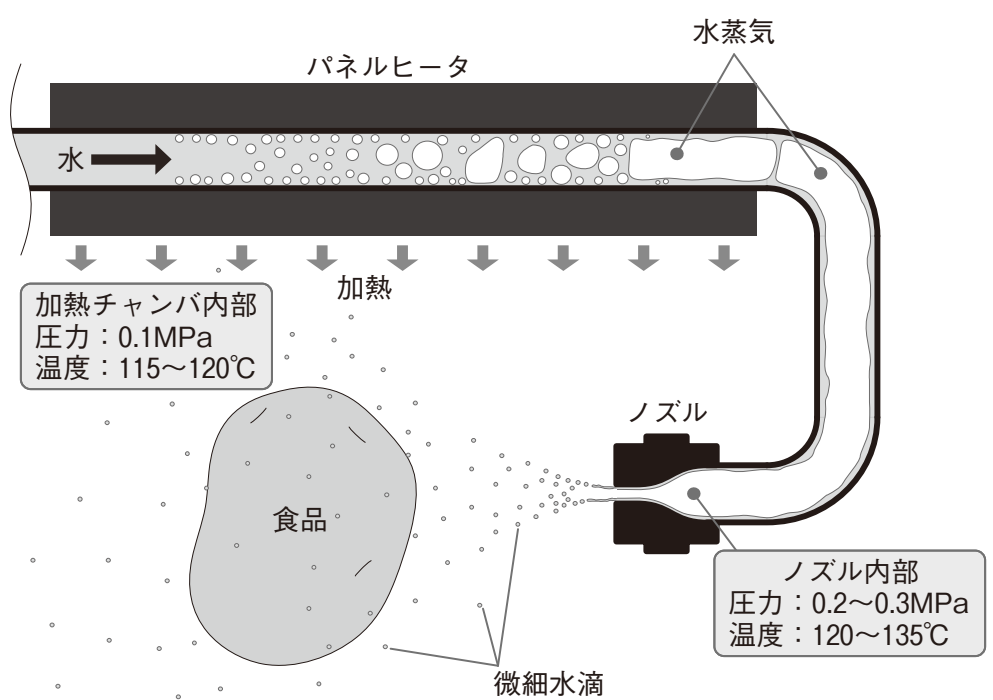

図 1 アクアガス発生メカニズム

定した。加熱チャンバー内処理温度は $115^{\circ} \mathrm{C}$, 酸素濃度 は0. $2 \%$ ，湿度は $100 \%$ であ。

調製した試料は穴あきホテルパン上に置き, 任意の秒 数アクアガス加熱を行った。

\section{（３）細菌検査試料の調製}

実験 1 ）の加熱時間については，予備実験においてア クアガス加熱後の試料を食味テストにより，食感，外観 が生の状態を保持できる最短加熱時間とした。実験 2 ), 3）の加熱時間については食材の種類や切り方により通 常の加熱時間を考慮して検討した。

\section{(4) 細菌検査の方法}

保存環境・殺菌効果の評価方法：試料はアクアガス加 熱後たたちに滅菌袋（96時間後測定分はポリエチレン ジッパー付袋）へ入れ密封し，保冷剤を並べた冷蔵室内 で十分に冷却した（チルド：0〜 $3{ }^{\circ} \mathrm{C}$ )。殺菌効果の評 価は一般生菌数の測定により行った。菌数測定は外部検 査機関に依頼したため, 加熱後冷却した検体はクール便 にて検査機関へ配送・測定を行った。物流の関係上検査
機関到着は翌日となるが，サンプル調製日を基準として 加熱後時間を表記した。なお一般生菌数は，混釈平板培 養法にて培養・測定したものである。

\section{3. 結果および考察}

衛生的に安全とされるレベルについては，弁当・惣菜 や洋生菓子など個別に衛生規範が提示されているが15, 16) がん研究振興財団助成研究の報告によれば, 移植食の一 般生菌数は $10^{3} \mathrm{cfu} / \mathrm{g}$ レベルでの提供を目標としている ${ }^{17)}$ そこで本報では $10^{3} \mathrm{cfu} / \mathrm{g}$ を衛生的に安全性が高いレベ ルと設定し，ほぼ無菌状態の300 cfu/g 以下については 特記することとした。

\section{（1）生食する食材のアクアガス加熱における短時間加 熱殺菌効果}

生の食感を保持したまま，かつ衛生的に安全な基準と なる最短のアクアガス加熱秒数と一般生菌数の結果を表 1 に示した。各々アクアガスで表記の秒数加熱すること により, 衛生的に安全な一般生菌数となった。数十秒と いう加熱時間でいずれも生の食感は保持したままで,

表 1 生食する食材のアクアガス加熱における短時間加熱殺菌効果

\begin{tabular}{|c|c|c|c|c|c|}
\hline 検体名 & $\begin{array}{l}\text { 加熱 } \\
\text { 時間 } \\
\text { (秒) }\end{array}$ & $\begin{array}{c}\text { 一般生菌数 } \\
\quad(\mathrm{cfu} / \mathrm{g})\end{array}$ & 検体名 & $\begin{array}{l}\text { 加熱 } \\
\text { 時間 } \\
\text { (秒) }\end{array}$ & $\begin{array}{c}\text { 一般生菌数 } \\
\quad(\mathrm{cfu} / \mathrm{g})\end{array}$ \\
\hline かぶ & 10 & $300 \geqq$ & 大根 & 20 & $300 \geqq$ \\
\hline ミニトマト & 10 & $300 \geqq$ & カットパイン & 20 & $300 \geqq$ \\
\hline カット野菜 & 10 & $10^{3}$ & 赤たまねぎ & 30 & $10^{2}$ \\
\hline 巨峰 ～～～～～～～ & 10 & $300 \geqq$ & ピーマン & 30 & $10^{2}$ \\
\hline メロン & 10 & $300 \geqq$ & にんじん & 30 & $300 \geqq$ \\
\hline レモン & 10 & $10^{2}$ & きゅうり（ホール） & 30 & $300 \geqq$ \\
\hline キャベツ（ざく切り） & 10 & $10^{3}$ & きゅうり（小口切り） & 30 & $300 \geqq$ \\
\hline キャベツ（せん切り） & 15 & $300 \geqq$ & きゅうり（せん切り） & 30 & $10^{2}$ \\
\hline パセリ & 15 & $10^{2}$ & & & \\
\hline
\end{tabular}


キャベッ, メロン, カットパイン等に扔いては食材の持 つ甘味が顕著に引き出された。

アクアガスの表面殺菌能力の高さはその熱伝達効率の 高さによるところが大きい。アクアガスとその他加熱法 の熱伝達効率の比較実験 ${ }^{5-7)}$ によると, アクアガスは速 やかに高温に達するため食材表面に付着している一般生 菌に対し有効に㗢きかけることができる。

加熱後の一般生菌数と生食感の保持については, 食材 の初発菌数や形状によるところが大きい。また, 組織が 薄く熱が内部まで短時間に伝わり物性が変化しやすいも のについては，生の食感を残したまま短時間で殺菌する ことができないと考元られている ${ }^{18}$ 。著者らの実験にお いても，レタス，大葉，ミズナ等を短時間加熱した場合 衛生的には問題ないが生の食感を保持することはできな かった。キャベッ等季節によってその品質が大きく異な る食材については，それぞれの品質に合わせて加熱秒数 の検討を行うことが必要である。

このように生の食感を損なわずに衛生的に安全に提供 できるという点は病院等でも注目されている。がん治療 により免疫不全状態にある患者に対しては，衛生的な観 点から危険性の高い生野菜やカット果実を提供できてい ない施設が多い。アクアガスによる短時間加熱殺菌はこ れを可能にし，患者の希望に応え QOL の向上をもたら している ${ }^{19}$ 。今後は学校給食等においても，アクアガス 加熱による衛生的に安全な生野菜サラダ等の提供を期待 したい。

\section{（2）生食および加熱食材の加熱後の一般生菌数の経時} 変化

アクアガス加熱により減少した一般生菌数が日持ち性 与える影響について, 加熱直後とチルド保存 96 時間後の 一般生菌数により評価した。

それぞれの検体の一般生菌数の経時的変化を図 2 , 図 3 に示した。未加熱の状態での一般生菌数は食材により $10^{3} \sim 10^{7} \mathrm{cfu} / \mathrm{g}$ であった。図 2 は初発菌数の多少にかか わらず，加熱直後に一般生菌数が $300 \mathrm{cfu} / \mathrm{g}$ 以下となっ
たものである。これらをチルド保存した96時間後, すべ ての検体に扔いて300 cfu/g 以下のままであった。この 結果から，アクアガス加熱により一般生菌数を $300 \mathrm{cfu} /$ $\mathrm{g}$ 以下に減少できると, 衛生的安全性が非常に高い状態 で日持ち性を向上できる可能性が高いことが示唆された。 1996年の食中毒事故以降，一般的に生で提供するのが難 しいとされているかいわれ大根 ${ }^{8)}$ をばめ農産物におい て，薬剂等を使用せずにこのような日持ち性を持たせら れることは画期的であると考える。

図 3 は加熱直後に比較的菌数が多かったものと，96時 間後の一般生菌数に増加がみられたものである。上述し たかいわれ大根の加熱処理時間を10秒にした場合の一般 生菌数を調べてみると，未加熱時 $10^{6} \mathrm{cfu} / \mathrm{g}$ で加熱直後 に $10^{4} \mathrm{cfu} / \mathrm{g}$ まで減少がみられた検体は，96時間後の一 般生菌数に増加はみられず， $10^{4} \mathrm{cfu} / \mathrm{g}$ のままであった。 また，その他食材に関しても加熱直後と96時間後の一般 生菌数に増加がみられず, $10^{4} \mathrm{cfu} / \mathrm{g}$ のままであった。

一方, 加熱直後の一般生菌数が多かった検体について は96時間後に $10^{6} \mathrm{cfu} / \mathrm{g}$ となった。これらの検体は食材 の組織が薄く食材間にアクアガスが十分に行き渡らない ため, 加熱直後の一般生菌数も $10^{5} \mathrm{cfu} / \mathrm{g}$ と多かったと 考元られる。しかし加熱直後と96時間後の一般生菌数の 増加は10倍に留まったので, 保存中に大幅に菌数が増加 したわけではないといえる。従来の殺菌法である中性洗 剤と次亜塩素酸ナトリウム溶液を用いた生野菜の保存実 験の報告によると，すすぎ・殺菌で一般生菌数には若干 の減少がみられ, $10^{\circ} \mathrm{C} \cdot 24$ 時間保存後には初発菌数より 増加し48時間後には $10^{7} \mathrm{cfu} / \mathrm{g}$ にまで達している ${ }^{200}$ 。これ と比較するとアクアガスによる加熱殺菌をした食材の一 般生菌数は，96時間後に増加をしても初発菌数を上回る ことはなく, 従来の殺菌法よりも保存性に優れていると 推察される。

アクアガス加熱による保存試験については調理品につ いても報告されている。豚角煮执よび牛スジ煮込みに打 いて $10^{\circ} \mathrm{C} \cdot 5$ 日間保存後, 通常調理法では一般生菌数の 増加がみられた（300 cfu/g 以下 $\rightarrow 10^{3} \mathrm{cfu} / \mathrm{g} ）$ のに対し

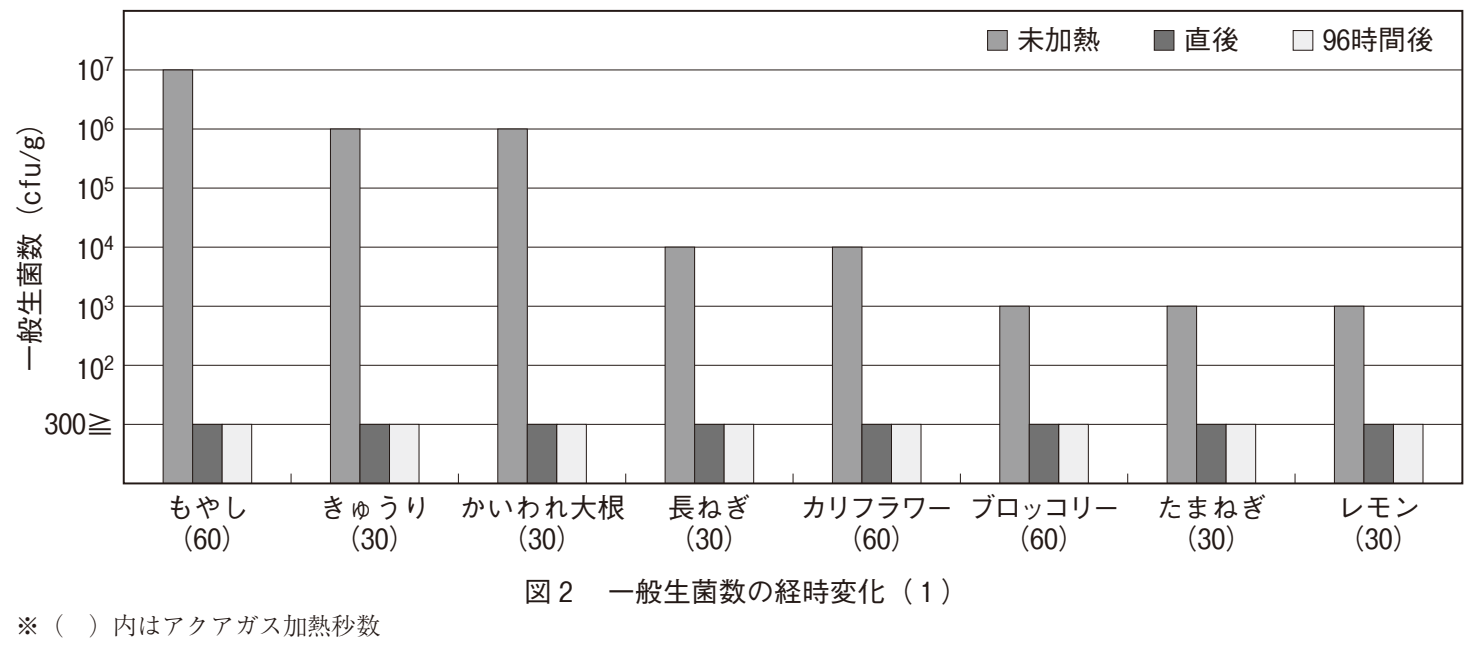

$118(46)$ 


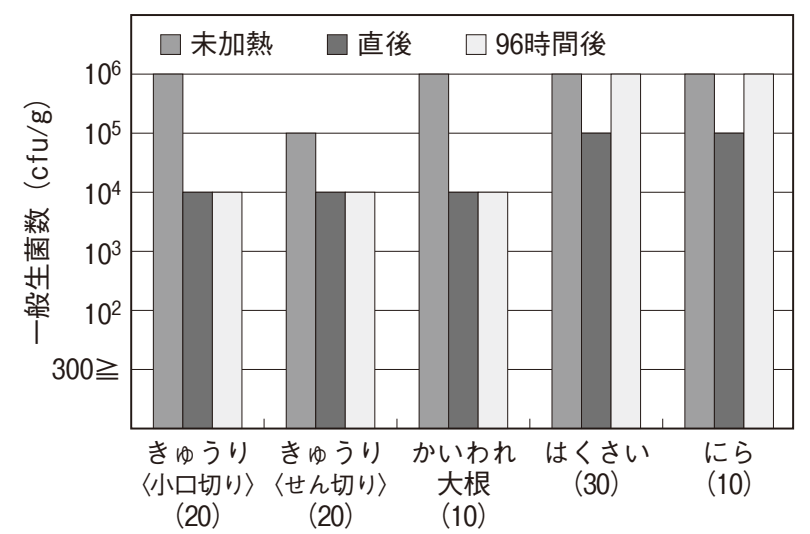

図 3 一般生菌数の経時変化 (2)

※（）内はアクアガス加熱秒数

アクアガス加熱による調理では300 cfu/g 以下のままと, 一般生菌数は抑制されていた ${ }^{9)}$ 。またポテトサラダにお いては $10^{\circ} \mathrm{C} \cdot 4$ 日間保存後, 通常調理法では一般生菌数 の増加がみられた $\left(10^{3} \mathrm{cfu} / \mathrm{g} \rightarrow 10^{5} \mathrm{cfu} / \mathrm{g}\right)$ のに対し, ア クアガス加熱では300 cfu/g 以下のままであった ${ }^{8)}$ 。

これらのことから，アクアガス加熱による一般生菌数の 減少は日持ち性の向上に大きく貢献できると判断できる。

\section{（３）アクアガス加熱時間の延長と殺菌効果}

加熱時間の延長が殺菌効果に及ぼす影響について検討 した結果を図 4 に示した。万能ねぎやたまねぎなど加熱 時間10秒では殺菌効果がみられなかったものにおいても,
加熱時間の延長により確実に一般生菌数は減少しており, 衛生的に安全な状態にまで殺菌できることが明らかに なった。きゅうりにおいて五月女らも，加熱時間を60秒 まで延長した結果一般生菌数が検出されなくなったと報 告している ${ }^{8,18)}$ 。どの食材においても微生物による污染 状況は, 流通・販売・保存状態にも左右されるため, 衛 生的に安全といえるレベルまで菌数を減少させるに要す る加熱時間は異なる。しかし生の食感を維持することよ りも衛生的に安全な一般生菌数にすることに着眼した場 合, アクアガス加熱時間の延長が確実な効果をあげるこ とが明らかになった。

生および加熱して使用される食材について，衛生的に 安全となる加熱時間の検討を行った結果を表 2 に示した。 これらは食材によって加熱の状態が異なるが加熱調理の 際のブランチング (予備加熱) として利用できると考え る。食材自体に菌数の多いもやしについては，30秒の加

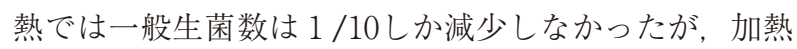
を60秒に延長したところ $300 \mathrm{cfu} / \mathrm{g}$ 以下まで減少させる ことができた。もやしは通常生で食すことはないため, 60秒の加熱を予備加熱として調理に利用できる。このよ うにアクアガスでの短時間加熱は食材に確実な殺菌効果 をもたらすとともに，高い熱伝達率による加熱時間の短 縮により作業工程の簡略化も図ることができる。さらに アクアガス加熱は通常の加熱方法と比べて, 食感・色 · おいしさ・栄養成分面についても評価が高いことがブ ロッコリー等において報告されており ${ }^{7,10)}$, 衛生的安全

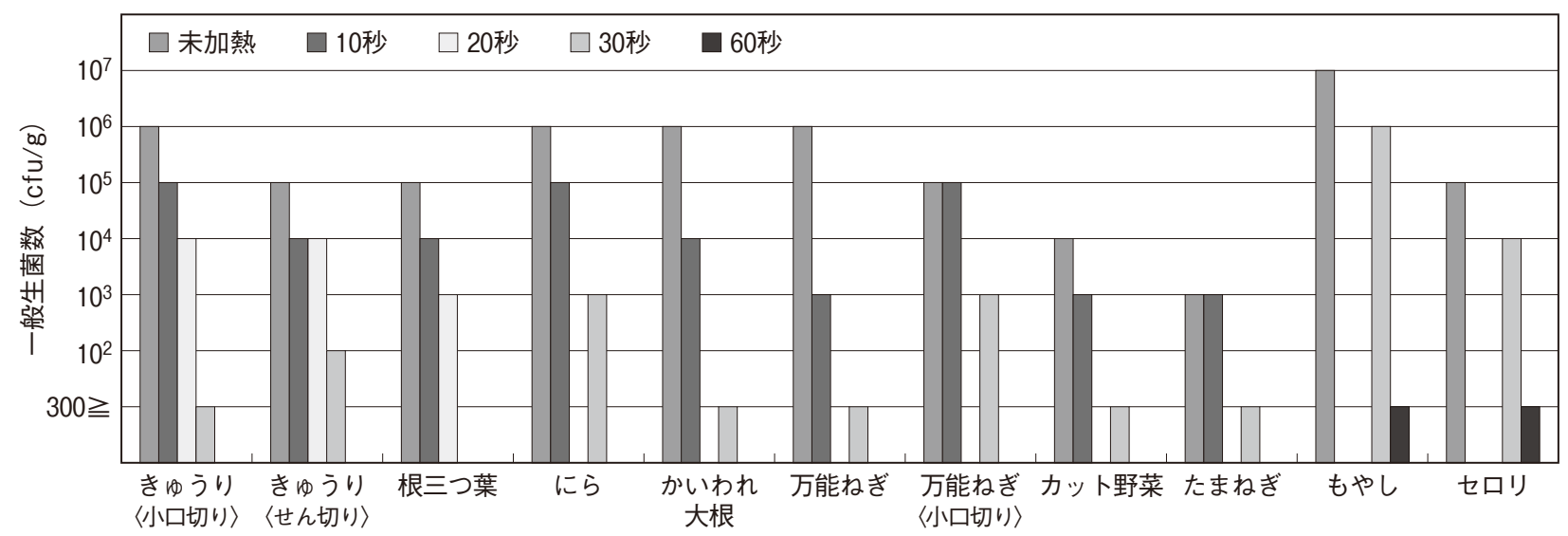

図 4 アクアガス加熱時間の延長と殺菌効果

表 2 衛生的に安全となるアクアガス加熱時間

\begin{tabular}{lcc|lcc}
\hline \multicolumn{1}{c}{ 検体名 } & $\begin{array}{c}\text { 加熱 } \\
\text { 時間 } \\
(\text { 秒 })\end{array}$ & $\begin{array}{c}\text { 一般生菌数 } \\
\text { (cfu/g) }\end{array}$ & 検体名 & $\begin{array}{c}\text { 加熱 } \\
\text { 時間 } \\
(\text { 秒 })\end{array}$ & $\begin{array}{c}\text { 一般生菌数 } \\
(\mathrm{cfu} / \mathrm{g})\end{array}$ \\
\hline 根三つ葉 & 20 & $10^{3}$ & ブロッコリー & 60 & $300 \geqq$ \\
長ねぎ & 30 & $10^{2}$ & セロリ & 60 & $300 \geqq$ \\
万能ねぎ & 30 & $10^{3}$ & もやし & 60 & $300 \geqq$ \\
にら & 30 & $10^{3}$ & 青梗菜 & 60 & $300 \geqq$ \\
かいわれ大根 & 30 & $300 \geqq$ & おくら & 60 & $300 \geqq$ \\
マッシュルーム & 45 & $300 \geqq$ & & & \\
\hline
\end{tabular}


性の高さと美味しさを併せ持った予備加熱にも効果的で あるといえる。これら十分に殺菌できた食材は，調理法 によっては適当な食感として扱えると考えられる。たと えばきゅうりの小口切りの場合, 10秒加熱なら生の食感 を十分に保持できるので生野菜サラダへ利用できる。20 秒加熱だとわずかにテクスチャーの变化がみられるが生 の食感は残るのでポテトサラダ用として，30秒まで加熱 時間を延長すると生とはいえない食感となるため塩もみ や漬物等への利用が考えられる。

このように食味, 食感を良好に保ちながら効果的な殺 菌効果を行えることは，惣菜類など加工食品の消費期限 の延長や安全性の向上に活用できると考えられる ${ }^{8,9)}$ 。

\section{4. 要 約}

アクアガス加熱による加熱殺菌効果を明らかにするこ とを目的に，さまざまな食材の生の食感を損なわない加 熱時間を検討し, 一般生菌数の測定, 保存実験㧍よび加 熱時間の延長による殺菌効果の検証を行った結果は以下 のと抢りである。

（1）多くの農産物において，アクアガス加熱10３0秒 で生の食感を保持しつつ衛生的に安全な状態となった。

（2）アクアガス加熱により一般生菌数が減少した食材 のほぼすべてにおいて96時間チルド保存後も一般生菌 数の増加がみられず，日持ち性を高めることができた。 （3）アクアガス加熱時間の延長は，一般生菌数を減少 させる傾向が認められた。

（4）アクアガス加熱による高い殺菌効果は，食材の保 存性を高めるため安全性が向上し, 加工食品の予備加 熱や加熱時間の短縮等，作業工程の簡略化にもつなが ることが推察された。

\section{謝辞}

この研究は株式会社タイヨー製作所, 有限会社梅田事 務所からの委託研究費により実施したものである。アク アガスの技術については, 独立行政法人農業・食品産業 総合研究機構・生物系特定産業技術研究支援センター （生研センター）の異分野融合研究支援事業で実施され た「アクアガスを用いた高品質沉用食材の新規調製技術 の開発」成果によるものである。ここに記して関係各位 に謝意を表する。

\section{文献}

1）農林水産省消費・安全局：生鮮野菜を衛生的に保つため に一栽培から出荷までの野菜の衛生管理指針一（2011）

2）太田義雄, 高谷健市, 中川禎人：次亜塩素酸ナトリウム によるキュウリの殺菌洗浄効果, 日本食品化学工学会誌, $42(9), 661-665(1995)$
3) 日高利夫, 桐ヶ谷忠司, 上條昌彌, 木川寛, 河村太郎, 河内佐十：次亜塩素酸ナトリウム処理野菜に打ける残留塩 素の消失とクロロホルムの生成, 食品衛生学雑誌，33（3）, 267-273（1992）

4）阿部茂：過熱水蒸気による農水産加工品の表面殺菌技術, フレッシュ食品の高品質殺菌技術，389-397（2008）

5 ）五月女格, 坂本晋子, 竹中真紀子, 小笠原幸雄, 名達義剛, 五十部誠一郎：微細水滴を含む過熱水蒸気の伝熱・乾燥特 性, 日本食品工学会誌，6（4），229-236（2005）

6 ）五十部誠一郎, 小笠原幸雄, 根岸由紀子, 殿塚婦美子： アクアガス（微細水滴含有過熱水蒸気） システムの開発と 農産加工への応用, 日本食品科学工学会誌, 58（8）, 351358 (2011)

7 ）五十部誠一郎：アクアガスの加熱機構と農産加工への応 用，日本食生活学会誌，17（3），193-197（2006）

8 ）五月女格，小関成樹，鈴木啓太郎，五十部誠一郎，山中 俊介, 小笠原幸雄, 名達義剛：微細水滴を含む過熱水蒸気 処理による野菜の高品質殺菌処理, 防菌防徽, 33 (10), 523-530 (2005)

9）山中俊介，五月女格，津田升子，竹中真紀子，小笠原幸雄, 名達義剛, 五十部誠一郎: 微細水滴を含んだ過熱水蒸気の 殺菌効果の評価と食品調理加工への応用, 防菌防徽, 35 (6), 341-349 (2007)

10）殿塚婦美子，長田早苗，谷武子，根岸由紀子，奥崎政美， 香川芳子：アクアガス加熱食材の基礎的調理加工特性に関 する研究 第 1 報 ブロッコリーについて, 日本食生活学 会誌, 16（3），242-248（2005）

11）五月女格，鈴木啓太郎，小関成樹，坂本晋子，竹中真紀子 小笠原幸雄, 名達義剛, 五十部誠一郎: 微細水滴を含む過 熱水蒸気によるジャガイモの 1 次加工処理, 日本食品科学 工学会誌, 53 (9), 451-458 (2006)

12）殿塚婦美子：アクアクッカーレシピ集 アクアクッカー で安全・高品質・簡単レシピ150選，アクアガス技術普及協 議会 (2013)

13） アクアガス技術普及協議会：アクアガスオーブン アク アクッカーカタログ

14）五十部誠一郎：アクアガスによる生鮮食材の殺菌と応用, フレッシュ食品の高品質殺菌技術，369-374（2008）

15）厚生省環境衛生局食品衛生課長通知：弁当及びそうざい の衛生規範について 環食第161号（1979）

16）厚生省環境衛生局食品衛生課長通知：洋生菓子の衛生規 範について 環食第五四号（1983）

17） がん研究振興財団助成研究：病院食での食品衛生状況の 現状と展望 微細水蒸気による殺菌効果の有用性と患者満 足度の向上に向けて 同種造血幹細胞移植に打ける食事内 容の見直し (報告書)， 3-4

18）五十部誠一郎：青果物 /カット青果物の衛生管理法と微 生物制御技術 [11] 物理的微生物制御技術（2）熱殺菌, 防菌防徽，35（8），519-526（2007）

19）桑原節子，松原弘樹，殿塚婦美子：がん治療患者（造血 幹細胞移植患者）に対する栄養食事管理の改善一微細水蒸 気の殺菌効果，臨床栄養，121（7），822-826（2012）

20）横山佳子：野菜サラダ加工過程における細菌叢の変化に 関する検討，日本食生活学会誌，24（1），21-27（2013） 